\title{
Cerebral Amyloid Angiopathy: Emerging Concepts
}

\author{
Masahito Yamada \\ Department of Neurology and Neurobiology of Aging, Kanazawa University Graduate School of Medical Sciences, Kanazawa, Japan
}

Cerebral amyloid angiopathy (CAA) involves cerebrovascular amyloid deposition and is classified into several types according to the amyloid protein involved. Of these, sporadic amyloid $\beta$-protein (AB)-type CAA is most commonly found in older individuals and in patients with Alzheimer's disease (AD). Cerebrovascular $A \beta$ deposits accompany functional and pathological changes in cerebral blood vessels (CAA-associated vasculopathies). CAA-associated vasculopathies lead to development of hemorrhagic lesions [lobar intracerebral macrohemorrhage, cortical microhemorrhage, and cortical superficial siderosis (cSS)/focal convexity subarachnoid hemorrhage (SAH)], ischemic lesions (cortical infarction and ischemic changes of the white matter), and encephalopathies that include subacute leukoencephalopathy caused by CAA-associated inflammation/angiitis. Thus, CAA is related to dementia, stroke, and encephalopathies. Recent advances in diagnostic procedures, particularly neuroimaging, have enabled us to establish a clinical diagnosis of CAA without brain biopsies. Sensitive magnetic resonance imaging (MRI) methods, such as gradient-echo $\mathrm{T}^{*}$ imaging and susceptibility-weighted imaging, are useful for detecting cortical microhemorrhages and cSS. Amyloid imaging with amyloid-binding positron emission tomography (PET) ligands, such as Pittsburgh Compound B, can detect CAA, although they cannot discriminate vascular from parenchymal amyloid deposits. In addition, cerebrospinal fluid markers may be useful, including levels of A 40 for CAA and anti-A $\beta$ antibody for CAA-related inflammation. Moreover, cSS is closely associated with transient focal neurological episodes (TFNE). CAA-related inflammation/angiitis shares pathophysiology with amyloid-related imaging abnormalities (ARIA) induced by $A \beta$ immunotherapies in AD patients. This article reviews CAA and CAA-related disorders with respect to their epidemiology, pathology, pathophysiology, clinical features, biomarkers, diagnosis, treatment, risk factors, and future perspectives.

\author{
Correspondence: Masahito Yamada \\ Department of Neurology and \\ Neurobiology of Aging, Kanazawa \\ University Graduate School of Medical \\ Sciences, Kanazawa 920-8640, Japan \\ Tel: $+81-76-265-2290$ \\ Fax: +81-76-234-4253 \\ E-mail:m-yamada@med.kanazawa-u. \\ ac.jp
}

Received: November 13, 2014

Revised: December 15, 2014

Accepted: December 24, 2014

The authors have no financial conflicts of interest.

Keywords Cerebral amyloid angiopathy; Amyloid $\beta$-protein; Cerebrovascular disorders; MRI; PET; Cerebrospinal fluid

\section{Introduction}

Cerebral amyloid angiopathy (CAA) involves cerebrovascular amyloid deposition. CAA was described as a cause of normotensive cerebral hemorrhage in older individuals or also described in studies focusing on its close association with Alzheimer's disease $(\mathrm{AD})$. The earlier terms to describe CAA include "drüsige Entartung der Arterien und Kapillaren," "aniopathie dyshorique," and "angiopathie congophile." ${ }^{3}$ The terms "drüsige Entartung” and "angiopathie dyshorique" represent a peculiar form of CAA showing perivascular plaque-like structures. Currently, CAA has been used as a general term to describe cerebrovascular amyloid deposition or cerebrovascular amyloidosis. ${ }^{4}$

CAA is classified into several types according to the amyloid protein involved (Table 1). So far, seven amyloid proteins have been reported in CAA including amyloid $\beta$-protein $(A \beta)$, cystatin $\mathrm{C}$ (ACys), prion protein (APrP), ABri/ADan, transthyre- 
Table 1. Classification of cerebral amyloid angiopathy (CAA)

\begin{tabular}{|c|c|}
\hline Amyloid protein & Clinical phenotype \\
\hline Amyloid $\beta$-protein $(A \beta)$ & $\begin{array}{l}\text { Sporadic; associated with: } \\
\text { Aging } \\
\text { Sporadic Alzheimer's disease (AD) } \\
\text { Other conditions, including vascular malformations, } \\
\text { irradiation } \\
\text { Hereditary or genetic; associated with: } \\
\text { Mutations in the amyloid } \beta \text {-protein precursor (AßPP) } \\
\text { gene, including hereditary cerebral hemorrhage with } \\
\text { amyloidosis-Dutch type (HCHWA-D) E6930, E693K } \\
\text { (Italian), E693G (Arctic), A6920 (Flemish), E694N } \\
\text { (lowa), L705V (Piedmont), A713T (Italian), and AßPP } \\
\text { gene duplication. } \\
\text { Mutations of presenilin genes } \\
\text { Down syndrome }\end{array}$ \\
\hline Cystatin C (ACys) & $\begin{array}{l}\text { HCHWA-Icelandic type (HCHWA-I) associated with } \\
\text { a mutation (68Leu } \rightarrow \mathrm{Gln} \text { ) of the cystatin C gene }\end{array}$ \\
\hline Prion protein (PrP) (APrP) & $\begin{array}{l}\text { Prion disease associated with mutations of the PRNP } \\
\text { gene (Y145Stop, Y163Stop, Y226Stop) }\end{array}$ \\
\hline ABri/ADan & $\begin{array}{l}\text { Familial British or Danish dementia (FBD/FDD) } \\
\text { associated with mutations of the BRI gene. }\end{array}$ \\
\hline Transthyretin (ATTR) & $\begin{array}{l}\text { Meningocerebrovascular involvement of familial } \\
\text { transthyretin (TTR) amyloidoses (familial } \\
\text { oculoleptomeningeal amyloidosis, familial amyloid } \\
\text { polyneuropathy) associated with mutations of the } \\
\text { TTR gene }\end{array}$ \\
\hline Gelsolin (AGel) & $\begin{array}{l}\text { Menigocerebrovascular involvement of gelsolin-related } \\
\text { amyloidosis (familial amyloidosis, Finnish type) } \\
\text { associated with mutations of the gelsolin gene }\end{array}$ \\
\hline $\begin{array}{l}\text { Immunoglobulin light } \\
\text { chain amyloid (AL) }\end{array}$ & $\begin{array}{l}\text { CAA with leukoencephalopathy due to brain-restricted } \\
\text { monoclonal plasma cell proliferation }\end{array}$ \\
\hline
\end{tabular}

tin (ATTR), gelsolin (AGel), and immunoglobulin light chain amyloid (AL); among these, sporadic CAA of the $A \beta$ type is most commonly found in older individuals as well as in patients with $\mathrm{AD}$ [see review $\left.{ }^{5}\right]$.

This article reviews sporadic A $\beta$-type CAA and CAA-related disorders with respect to their epidemiology, pathology, pathophysiology, clinical features, biomarkers, diagnosis, treatment, risk factors, and future perspectives.

\section{Epidemiology, pathology, and pathophysiology of CAA}

The prevalence of CAA increases with age, ${ }^{6,7}$ and CAA occurs in approximately half of elderly individuals. ${ }^{6} \mathrm{CAA}$ is commonly observed in $\mathrm{AD}$ with a prevalence of about $80 \%-90 \%$., CAA-related lobar intracerebral hemorrhage (ICH), identified via a nationwide survey in Japan, increases with age and presents with female predominance. ${ }^{9}$

Pathologically, CAA is observed mainly in the leptomeningeal and cortical vessels of the cerebral lobes and cerebellum. For the distribution of CAA, the occipital lobe is preferentially af- fected, ${ }^{6}$ whereas CAA is uncommon in the basal ganglia, thalamus, brainstem, and white matter. In mild CAA, a small proportion of the leptomeningeal and superficial cortical vessels are affected with amyloid deposition. In severe CAA, most small arteries and arterioles are affected with marked amyloid deposition. Medium-sized leptomeningeal arteries show amyloid deposition in the outer regions of the media to the adventitia. Vessel walls of the small arteries and arterioles are often totally replaced by amyloid deposits, except for the endothelial cells. Electron microscopically, amyloid fibrils are focally deposited within the outer basement membrane of the vessels during the initial stage of CAA. ${ }^{10}$ Later, a large amount of amyloid fibrils accumulate with degeneration of smooth muscle cells of the media (Figure 1A). Amyloid deposits in capillaries and, occasionally, in arterioles or small arteries appear to infiltrate the surrounding parenchymal tissue, and accompany dystrophic neurites forming plaque-like structures (drüsige Entartung ${ }^{1}$ /angiopathie dyshorique ${ }^{2}$ ). Recently, CAA in capillaries has been referred to as "capillary CAA (CAA-Type 1)," to distinguish it from non-capillary CAA (CAA-Type 2). ${ }^{11}$ Severe CAA is associated with vasculopathies including duplication ("double-barrel" lumen), obliterative intimal changes, hyaline degeneration, microaneurysmal dilatation, and fibrinoid necrosis (Figure 1B, C). ${ }^{12-14}$ These CAA-associated vasculopathies are the pathological basis of CAA-related cerebrovascular disorders. In particular, fibrinoid necrosis is closely associated with CAA-related hemorrhage. ${ }^{12-14}$

$\mathrm{A} \beta$ is cleaved from the $\beta$-amyloid precursor protein (A $\beta \mathrm{PP})$ by $\beta$-secretase and $\gamma$-secretase. Heterogeneity of the $\mathrm{C}$-terminal is present, and the length of $A \beta$ in senile plaques is mainly 4243 residues (A $\beta 42)$, while that of cerebrovascular $A \beta(C A A)$ is mainly 39-40 residues (A $\beta 40)$ (Figure 2) ${ }^{15,16}$ Recent studies suggest that $A \beta$ in $C A A$ is derived from the brain [see review ${ }^{5}$; after release from neurons, $A \beta 42$ easily aggregates and deposits in the brain parenchyma as senile plaques; whereas, $A \beta 40$ does not aggregate as easily as $A \beta 42$, and is transported, through periarterial interstitial fluid drainage pathways, to blood vessels for clearance. In this process, $A \beta 40$ aggregates on vascular basement membranes, as first proposed by Weller. ${ }^{17}$

The pathophysiology of A $\beta$-type CAA is shown in Figure $3 .{ }^{18}$ CAA-associated vasculopathies lead to development of hemorrhagic lesions [lobar intracerebral macrohemorrhage, cortical microhemorrhage, and cortical superficial siderosis (cSS)/focal convexity subarachnoid hemorrhage (SAH)], ischemic lesions (cortical infarction and ischemic changes of the white matter), and encephalopathies that include subacute leukoencephalopathy caused by CAA-related inflammation/angiitis (Figure 1). In addition, $\mathrm{CAA}$ is related to dementia through $\mathrm{AD}$ pathology 

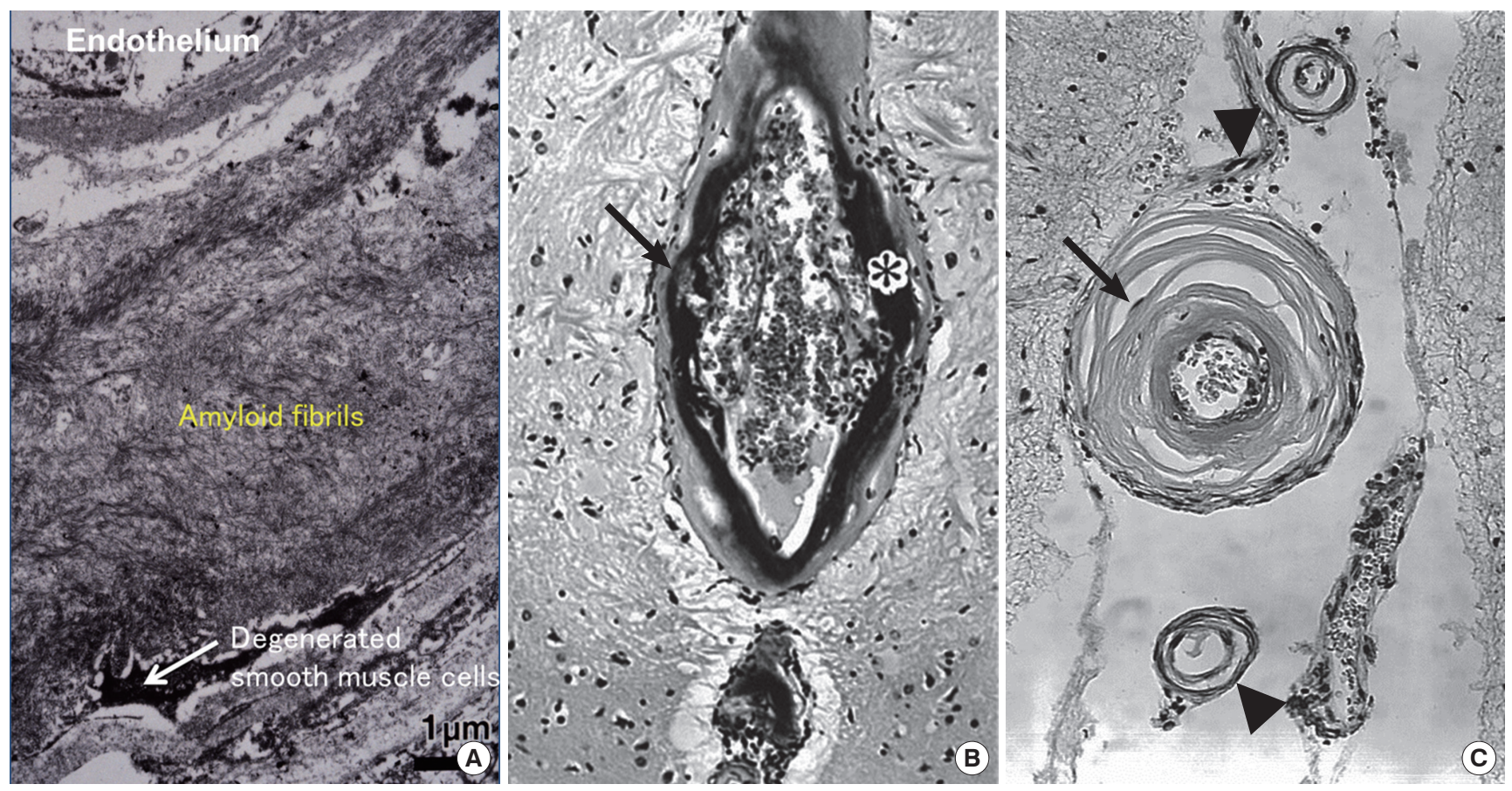

Figure 1. CAA and CAA-associated vasculopathies. Massive amyloid deposition of amyloid fibrils with degeneration of smooth muscle cells in the media (A). Microaneurysmal dilatation (arrow) with fibrinoid necrosis $\left(^{*}\right)(B)$. Thickening of the intima (arrow) and double barreling of vascular walls (arrowheads) (C). (A, electron micrograph, bar $=1 \mu \mathrm{m}$; B, Congo red, original magnification $110 x$; C, Congo red, original magnification $170 \times$ ).
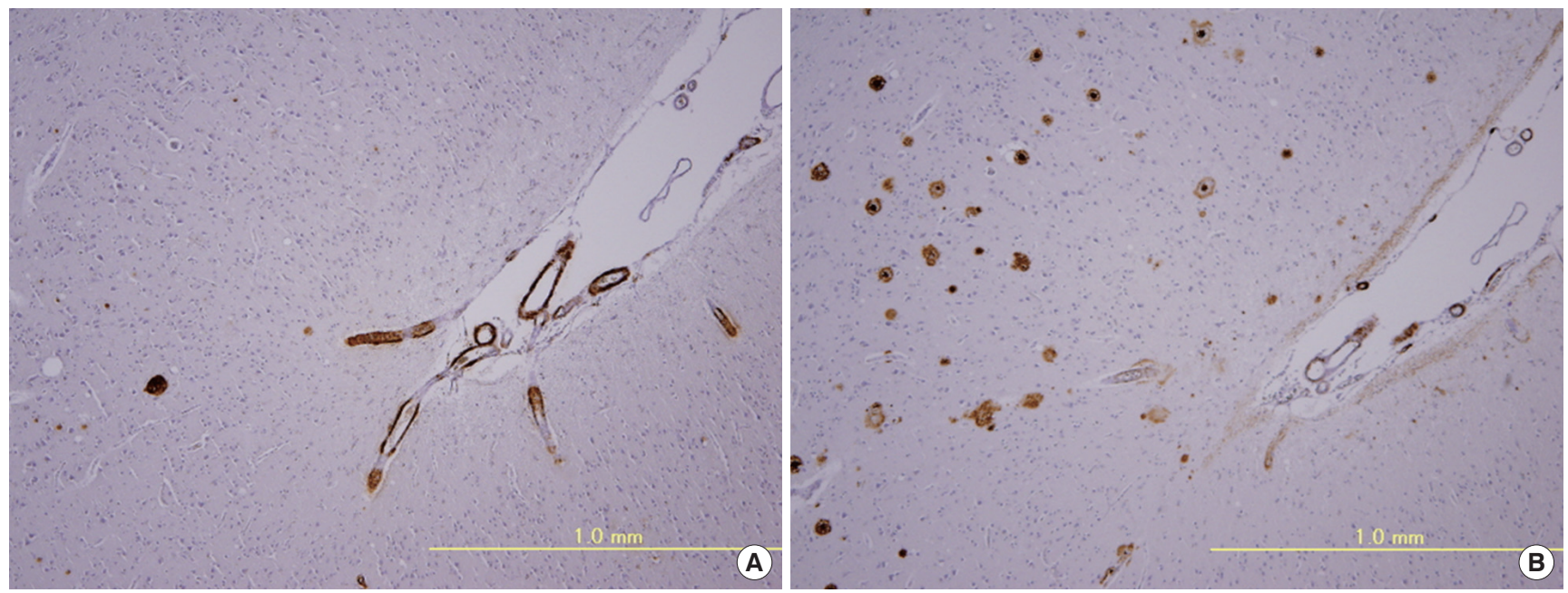

Figure 2. Immunohistochemistry of adjacent brain sections with antibodies to $A \beta 40(A)$ and $A \beta 42(B)$. Positive immunoreactivity to $A \beta 40$ is mainly observed in vessel walls (CAA) (A), whereas $A \beta 42$ immunoreactivity is mainly observed in the brain parenchyma (senile plaques) (B).

and CAA-related vascular lesions (Figure 1). Thus, CAA is related to dementia, stroke, and encephalopathies.

\section{Clinical aspects of CAA-related disorders}

\section{Clinical features}

\section{Intracerebral hemorrhages}

Symptomatic lobar intracerebral hemorrhages (ICH)

CAA is significantly associated with lobar intracerebral hem- orrhage (ICH) (Figure 4A), but not with deep $\mathrm{ICH},{ }^{19}$ because sporadic $A \beta$-type CAA is commonly found in the meningeal and cortical vessels of cerebral and cerebellar cortices, and rarely in those of the deep gray matter including basal ganglia, thalamus, and brainstem. ${ }^{6}$ Using the SMASH-U system (structural lesion, medication, amyloid angiopathy, systemic/other disease, hypertension, undetermined) as a pathogenetic classification system for ICH, CAA-related ICH was noted in $20 \%$ of ICH cases in the Helsinki ICH study, ${ }^{20}$ and $12 \%$ of ICH cases in the 


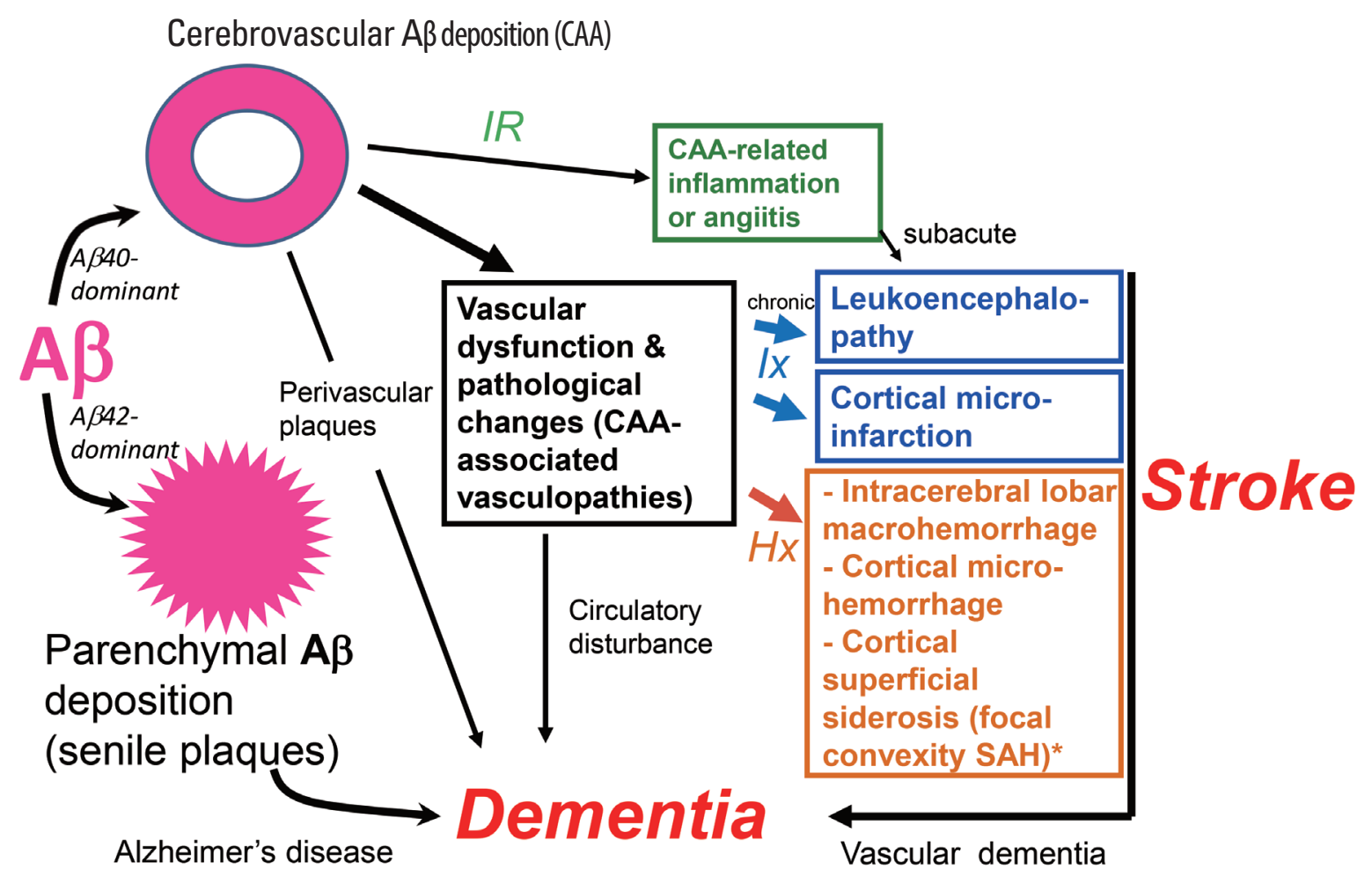

Figure 3. Pathophysiology of cerebral amyloid angiopathy (CAA)-related disorders. A $\beta$ shows parenchymal (senile plaques) or vascular deposition (CAA) depending on dominance of $A \beta 42$ or $A \beta 40$, respectively. $C A A$ is related to stroke and dementia. Hx, hemorrhagic events; Ix, ischemic events; IR, immune reaction against $A \beta$.

National Taiwan University Hospital Stroke Registry. ${ }^{21}$ CAArelated ICH was the second most common cause of ICH following hypertensive angiopathy in these studies. ${ }^{20,21}$ The incidence of lobar ICH in the elderly has been increasing recently, in which CAA is strongly implicated. ${ }^{22}$ CAA-related lobar ICH is often multiple and recurrent, and clinical manifestations include motor paresis, disturbance of consciousness, abnormalities in higher brain functions, such as aphasia, visual loss, with headache at the acute stage, and dementia and seizures during chronic stages. ${ }^{9}$ Headache with meningeal signs is likely caused by subarachnoid hemorrhage (SAH) accompanying lobar $\mathrm{ICH}^{23-25}$

\section{Cortical microhemorrhages}

Cerebral microhemorrhages (microbleeds) were noted in $16.7 \%-32 \%$ of $\mathrm{AD}$ patients, which is higher than in the general population (5\%-6\%), when examined by gradient-echo $\mathrm{T} 2$ * $\mathrm{MRI},{ }^{26-30}$ and in $78 \%$ of patients with $\mathrm{AD}$ or mild cognitive impairment (MCI) on ultra-high field strength 7T MRI. ${ }^{31}$ Microhemorrhages were found in $47.4 \%$ of patients with pathologically confirmed CAA cases. ${ }^{32}$ CAA-related microhemorrhages are frequently lobar in distribution (Figure 4B). Studies with amyloid positron emission tomography (PET) using 11CPittsburgh Compound B (PiB) reported that lobar microhemorrhages are frequently found in PiB-positive healthy subjects as well as patients with $\mathrm{AD}$ or mild cognitive impairment (MCI), ${ }^{33}$ and that microhemorrhages preferentially occur in local regions of concentrated amyloid deposits. ${ }^{34}$ New hemorrhages occur preferentially at the sites of increased amyloid deposits, suggesting that amyloid imaging may be useful to predict future CAA-related hemorrhages. ${ }^{35}$ Patients with lobar microhemorrhages are at considerable risk of future symptomatic lobar ICH. ${ }^{36}$

\section{Cortical superficial siderosis/focal convexity subarachnoid} hemorrhages

CAA is a frequent cause of cSS/focal convexity SAH (Figure 4C), a subtype of nonaneurysmal SAH, in patients over the age of 60 and in those with $\mathrm{AD} \cdot{ }^{32,37,38}$ Notably, cSS is closely associated with microhemorrhages in lobar locations in the general population. ${ }^{39}$ Moreover, cSS occurs with high prevalence in CAA and is found in $60.5 \%$ of pathologically confirmed cases. ${ }^{32,40}$ Interestingly, cSS tends to occur in individuals with relatively fewer cortical microhemorrhages, suggesting differences in vasculopathic changes between CAA-related microhemorrhages and $\mathrm{cSS} .{ }^{41}$ Furthermore, $\mathrm{cSS}$ is associated with an increased future risk of symptomatic lobar $\mathrm{ICH}^{40,42}$ The prevalence of cSS is higher in patients with $\mathrm{AD}$ or cognitive impairment than in the general population. ${ }^{43,44}$ Interestingly, cSS has been reported to present with transient focal neurological epi- 

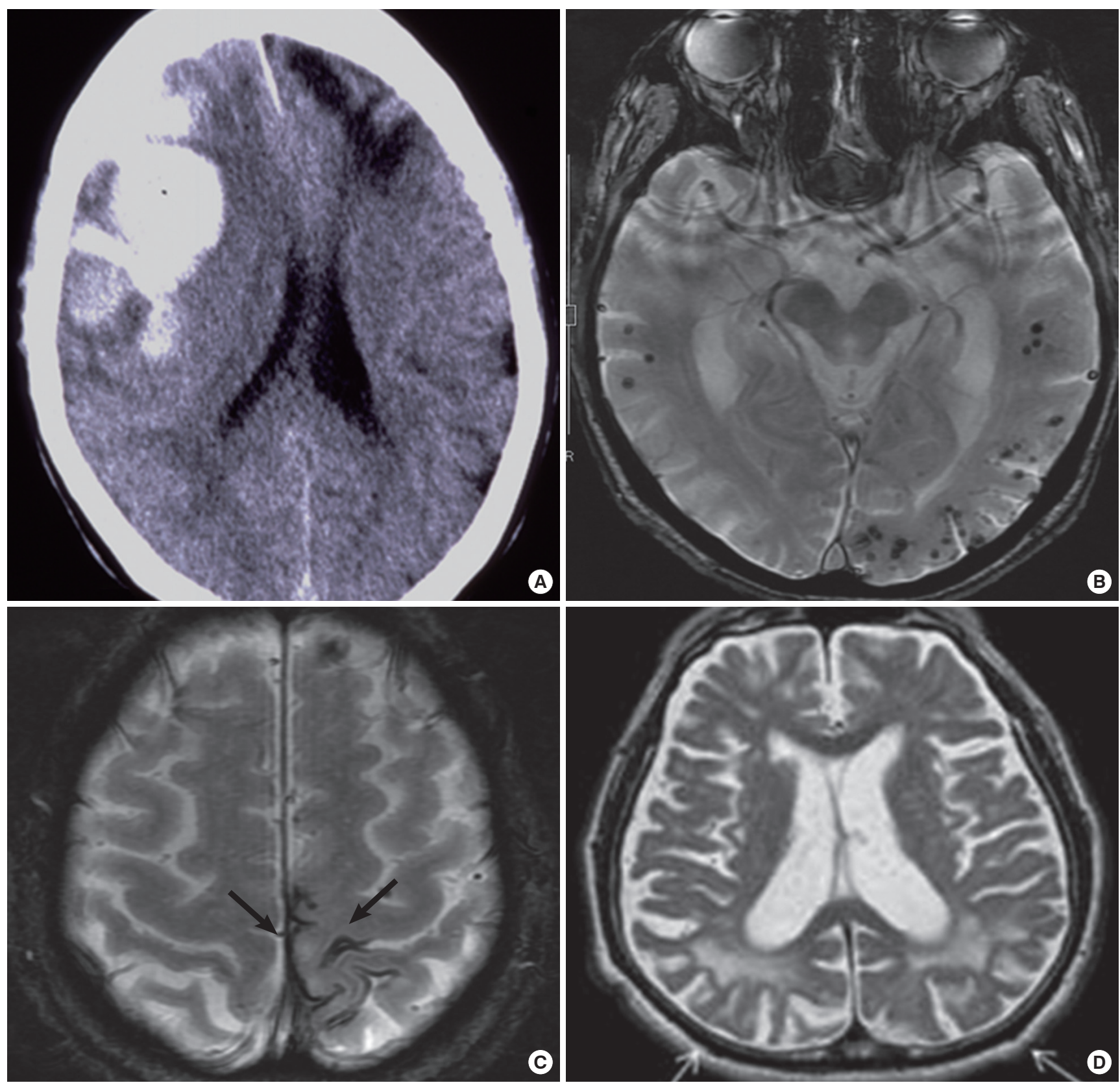

Figure 4. Imaging findings of CAA-related hemorrhages and white matter lesions. Fresh (arrow) and old (arrowhead) lobar macrohemorrhages in the frontal lobes on CT (A). Cortical microhemorrhages with lobar distribution (B) and focal subarachnoid hemorrhages (superficial siderosis) (C) on gradient echo T2*-weighted MRI. Posterior distribution of white matter hyperintensities (arrows on T2-weighted MRI) (D).

sodes (TFNEs); TFNEs are a clinical marker of cSS and may be caused by cSS through cortical spreading depression or focal seizure activity. ${ }^{45-49}$ Anti-platelet or anticoagulant therapies based on the misdiagnosis of CAA-related TFNE as a transient ischemic attack may induce CAA-related ICH.

\section{White matter disease and cortical infarction}

CAA-related cerebral hypoperfusion or occlusive small-vessel disease may cause progressive white matter lesions and cortical microinfarcts. Patients with CAA-related ICH exhibit occipital dominant white matter hyperintensities (WMHs) on MRI (Figure 4D), compatible with predilection of CAA pathology for posterior brain regions. ${ }^{50}$ A posterior distribution of $\mathrm{WMH}$ on MRI is associated with the presence of CAA pathology. ${ }^{51}$ Amyloid burden in non-demented CAA subjects correlated with $\mathrm{WMH}$ volumes. ${ }^{52}$ Acute or subacute subclinical ischemic infarcts are common in CAA-related $\mathrm{ICH}^{53-55}$ As a result of the difficulty in detection (see below), CAA as a cause of cortical 
microinfarcts is underrecognized.

\section{Dementia}

$\mathrm{CAA}$ with hemorrhagic/ischemic vascular lesions or $\mathrm{AD}$ pathology may be associated with dementia during its clinical course, ${ }^{56}$ although dementia is found only in a subgroup of patients with CAA-related $\mathrm{ICH}$ at the onset of the initial $\mathrm{ICH} .57$ Dementia was noted in $74 \%$ of individuals with severe CAA at autopsy. ${ }^{56}$ Moderate-to-very severe CAA is associated with impaired performance in specific cognitive domains, most notably perceptual speed, which is separate from the effect of $\mathrm{AD}$ pathology. ${ }^{58}$

\section{CAA-related inflammation}

CAA is commonly associated with immune reactions of monocyte/macrophage-lineage cells. ${ }^{59} \mathrm{CAA}$ can be accompanied by marked inflammation (CAA-related inflammation/angiitis), presenting with subacute leukoencephalopathy that is responsive to immunosuppressive therapies..$^{59-63}$ The clinical symptoms include subacute cognitive impairment or seizure, which are different from those of hemorrhagic stroke in noninflammatory CAA. Inflammatory CAA is also characterized by asymmetric T2-hyperintense white matter lesions on MRI. ${ }^{59-63}$ CAA-related inflammation is associated with an increase in anti-A $\beta$ antibodies in cerebrospinal fluid (CSF) ${ }^{64,65}$ CAA-related inflammation/angiitis shares pathophysiology with amyloidrelated imaging abnormalities (ARIA) induced by $A \beta$ immuno- therapies, as discussed below.

\section{Biomarkers and diagnosis Imaging markers $C T / M R I$}

Cranial CT is an option for macrohemorrhages; however, sensitive MR imaging techniques, such as gradient-echo $\mathrm{T} 2$ * imaging and susceptibility-weighted imaging, are useful for detecting microhemorrhages and $\mathrm{cSS} .{ }^{66} \mathrm{~A}$ posterior distribution of WMH is a possible marker of CAA. ${ }^{51}$ Although acute or subacute cortical or subcortical infarctions can be recognized in CAA on diffusion-weighted images, ${ }^{53}$ cortical microinfarcts are often undetected on MRI because of their limited size. ${ }^{31}$ Ultrahigh strength clinical MR scanners with a higher spatial resolution may enable their detection. ${ }^{67} \mathrm{CT}$ angiography spot signs, suggestive of an acute bleeding process, are associated with warfarin use and ICH volume in both CAA-related lobar ICH and arteriolosclerotic deep $\mathrm{ICH} .{ }^{68}$ Enlarged perivascular spaces in the centrum semiovale are associated with CAA, suggesting an imaging marker for CAA. ${ }^{69-71}$

\section{Functional imaging}

Impaired vascular reactivity in response to visual stimulation or a visual task in CAA was reported in studies with transcranial Doppler ultrasound and functional MRI, consistent with greater distribution of CAA in the occipital lobe..$^{72-74}$
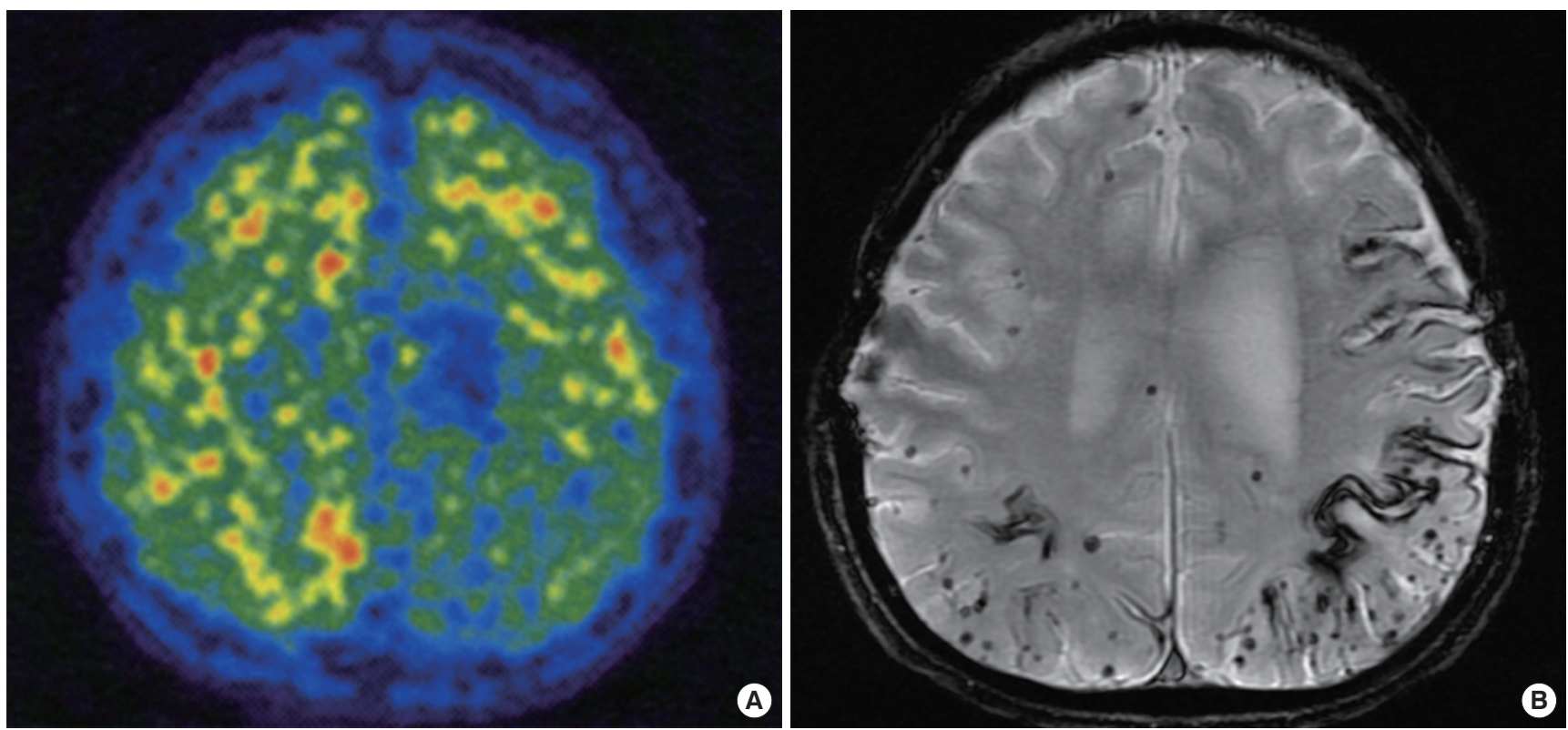

Figure 5. Amyloid positron emission tomography (PET) using ${ }^{11} \mathrm{C}$-Pittsburgh Compound B (PiB) (A) with gradient echo T2*-weighted MRI (B) in a non-demented patient with multiple CAA-related intracerebral hemorrhages and disseminated cortical superficial siderosis. The left parietal region with an old intracerebral hemorrhage shows a relative scarcity of $\mathrm{PiB}$ uptake. 


\section{Amyloid PET}

Amyloid imaging with the PET ligand, PiB, revealed an increase of $\mathrm{PiB}$ binding that often shows greater occipital uptake in CAA-related ICH (Figure 5). ${ }^{75-77}$ Microhemorrhages are associated with $\mathrm{PiB}$ retention, ${ }^{33,34}$ and new CAA-related hemorrhages preferentially occur at sites of $\mathrm{PiB}$ retention. ${ }^{35}$ As a frequent occurrence of high $\mathrm{PiB}$ uptake in healthy elderly individuals reflects incipient $\mathrm{AD}, \mathrm{PiB} P \mathrm{PET}$ has low specificity for $\mathrm{CAA}$; however, a negative $\mathrm{PiB}$ scan rules out $\mathrm{CAA}$ with excellent sensitivity. ${ }^{78}$ Amyloid imaging with such PET ligands as PiB cannot discriminate vascular from parenchymal deposition or $A \beta$ from other amyloid proteins; reagents specific for vascular $A \beta$ deposition are favorable candidates for amyloid imaging specific for A $\beta$-type CAA. ${ }^{79}$

\section{Biochemical markers}

A significant decrease in cerebrospinal fluid (CSF) levels of $A \beta 40$ as well as $A \beta 42$ was reported in patients with probable CAA, which suggests trapping of $A \beta 40$ and $A \beta 42$ in the cerebral vasculature. Furthermore, CSF levels of total tau and phosphorylated tau are higher in patients with probable CAA than in controls, but lower than in $\mathrm{AD}{ }^{80,81}$ It was reported that patients with CAA-related ICH exhibit higher plasma levels of $A \beta 42, A \beta 40$, and specific $A \beta$ fragments. ${ }^{82}$ The presence of anti$\mathrm{A} \beta$ autoantibodies in CSF is a marker of CAA-related inflammation. ${ }^{64,65}$

\section{Diagnosis}

The Boston criteria were proposed for the diagnosis of CAArelated ICH (Table 2), and high diagnostic accuracy was reported with a small pathologic series. ${ }^{83}$ As hypertension may cause lobar $\mathrm{ICH}^{23}$ exclusion of advanced hypertension may increase the specificity of the diagnosis of CAA-related $\mathrm{ICH}$; however, the diagnostic sensitivity is decreased, ${ }^{9}$ because CAA may coexist with hypertension.

When cSS was incorporated into the classic Boston criteria (the modified Boston criteria) (Table 2), the sensitivity increased from $89.5 \%$ to $94.7 \%$, and the specificity was $81.2 \%$ for both the classic and modified criteria. ${ }^{32}$

\section{Current treatment and prognosis}

Currently, no disease-modifying therapies are available for CAA. As for neurosurgery for CAA-related $\mathrm{ICH}$, uncontrollable peri- and post-operative hemorrhages have been reported previously; however, recent studies suggest that neurosurgical procedures, especially hematoma evacuation, can be performed more safely than previously expected. ${ }^{84}$ In our study involving a nationwide survey in Japan, ${ }^{9}$ neurosurgical procedures were
Table 2. Classic ${ }^{83 *}$ and modified Boston criteria ${ }^{32 \dagger}$ for diagnosis of CAA-related hemorrhage

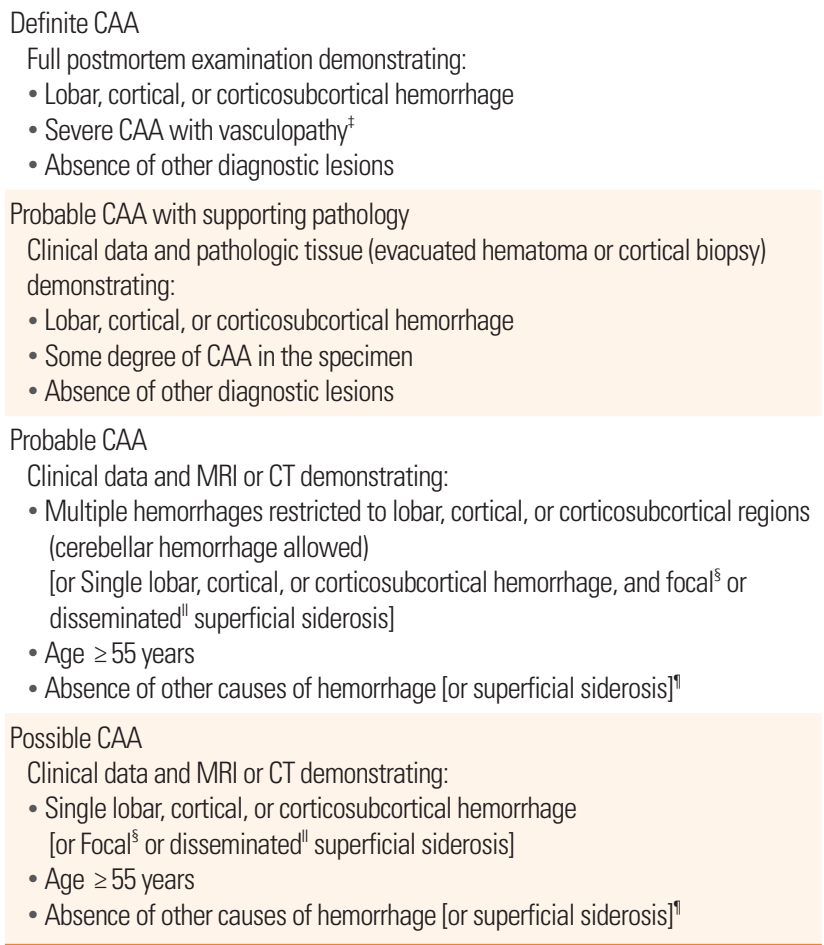

*Criteria established by the Boston Cerebral Amyloid Angiopathy Group: Steven M. Greenberg, MD, PhD, Daniel S. Kanter, MD, Carlos S. Kase, MD, and Michael S. Pessin, MD.

'The modified criteria are indicated in [ ].

${ }^{\ddagger}$ As defined in: Vonsattel JP, Myers RH, Hedley-Whyte ET, Ropper AH, Bird ED, Richardson EP Jr. Cerebral amyloid angiopathy without and with cerebral hemorrhages: a comparative histological study. Ann Neuro/ 1991;30:637-649.

§Siderosis restricted to 3 or fewer sulci.

"Siderosis affecting at least 4 sulci.

"Other causes of intracerebral hemorrhage: excessive warfarin (international normalization ratio, INR > 3.0); antecedent head trauma or ischemic stroke; central nervous system tumor, vascular malformation, or vasculitis; and blood dyscrasia or coagulopathy. INR $>3.0$ or other nonspecific laboratory abnormalities permitted for diagnosis of possible CAA.

performed without uncontrollable intra-operative or post-operative hemorrhage in $97.1 \%$ of patients. CAA-related lobar ICH recurred in $31.7 \%$ of patients during the average 35.3-month follow-up period. The mean interval between ICHs was 11.3 months and the case fatality rate was $12.2 \%$ at 1 month and $19.5 \%$ at 12 months after initial ICH. Subacute leukoencephalopathy associated with CAA-related inflammation or angiitis was reported to respond to immunosuppressive treatment. ${ }^{61-63}$

\section{Risk factors of CAA and CAA-related disorders}

Aging and $\mathrm{AD}$ are established risk factors of $\mathrm{CAA}_{;}{ }^{5}$ besides these, genetic and non-genetic risk factors have been reported for CAA and CAA-related disorders. 


\section{Genetic risk factors}

\section{Apolipoprotein E gene}

In addition to hereditary cases of $\mathrm{AD} / \mathrm{CAA}$ associated with mutations of the A $\beta \mathrm{PP}$ or presenilin genes [see review ${ }^{5}$ ], the ApoE gene $(A p o E)$ has been reported to be risk factor for sporadic $\mathrm{CAA}$ as well as $\mathrm{AD}$; the $\varepsilon 4$ allele for CAA itself, and the $\varepsilon 2$ allele for CAA-related $\mathrm{ICH}^{85-87}$ and hematoma expansion. ${ }^{88}$ Carriers of the $A p o E \varepsilon 2$ or $\varepsilon 4$ allele, particularly, of the ApoE $\varepsilon 2 /$ $\varepsilon 4$ genotype were associated with early recurrence of lobar $\mathrm{ICH}$ in patients who survived a lobar $\mathrm{ICH} .{ }^{89}$ The ApoE $\varepsilon 4$ allele constitutes a risk factor for capillary CAA (CAA-Type 1), ${ }^{11}$ CAArelated inflammation, ${ }^{63}$ and brain microhemorrhages. ${ }^{90}$ Furthermore, ApoE $\varepsilon 2$ was overrepresented in patients with $c S S .{ }^{41}$ The presence of CAA in head injury cases was significantly associated with the $A p o E \varepsilon 4$ allele, suggesting an interaction between gene and environment in the development of CAA. ${ }^{91}$

\section{Other genetic factors}

Transforming growth factor (TGF)- $\beta 1$ is another CAA-related gene reported by more than one research group. ${ }^{92,93}$ In addition, CAA was reported to be associated with other gene polymorphisms, including the presenilin 1 (PS1), a1-antichymotrypsin (ACT), neprilysin, low-density lipoprotein-receptor related protein (LRP-1), and angiotensin-converting enzyme (ACE) genes. ${ }^{8,94-100}$ Furthermore, a CR1 gene polymorphism, reported to increase the risk of $\mathrm{AD}$, was also reported to be associated with increased risk of CAA-ICH and CAA. ${ }^{101}$

\section{Non-genetic risk factors}

\section{Hypertension}

Lowering of blood pressure reduced the risk of CAA-related $\mathrm{ICH}$, suggesting that high blood pressure could be a factor inducing ICH in patients with CAA. ${ }^{102}$ Hypertension could contribute to progression of CAA-associated vasculopathies, particularly fibrinoid necrosis, leading to the development of CAArelated $\mathrm{ICH}$. It was reported that the prevalence of hypertension was significantly higher in autopsy-confirmed CAA patients with $\mathrm{ICH}$ than in those without $\mathrm{ICH}$, suggesting a role for hypertension in the development of CAA-related $\mathrm{ICH}^{13}$

\section{Thrombolytic, anticoagulation, and antiplatelet therapies}

There is increasing evidence that CAA could be a risk factor for ICH with thrombolytic therapies for acute myocardial infarction, pulmonary embolism, or ischemic stroke, and for ICH with warfarin therapies. ${ }^{103,104}$ Thrombolytic or anticoagulation therapies in patients with micorhemorrhages are a potential risk factor for $\mathrm{ICH}^{36,105,106}$ The ApoE $\varepsilon 2$ and $\varepsilon 4$ alleles were reported as strong risk factors for lobar warfarin-related $\mathrm{ICH}$; this associ- ation was considered to be mediated by the effect of $A p o E \varepsilon$ variants on CAA. ${ }^{107}$ The use of anti-platelet drugs, such as aspirin, is associated with the presence of microhemorrhages, and with strictly lobar microhemorrhages suggestive of CAA. ${ }^{108}$ In a systematic review of clinical trials with aspirin in $\mathrm{AD}, \mathrm{ICH}$ was noted in $3.2 \%$ of patients in the aspirin group, but in $0 \%$ of the control group, suggesting that aspirin use in $\mathrm{AD}$ might increase the risk of ICH. A possible explanation for the increased risk of $\mathrm{ICH}$ could be $\mathrm{CAA}$ in $\mathrm{AD}{ }^{109}$

\section{Anti-amyloid therapies}

Clinical and experimental studies of $A \beta$ immunotherapies for $\mathrm{AD}$ have reported $\mathrm{CAA}$-related complications. In clinical trials with $\mathrm{A} \beta 42$ immunization for $\mathrm{AD}$ (AN1792, Elan), immunized patients showed a significantly greater frequency of CAA, cortical microhemorrhages, and microvascular lesions than unimmunized $\mathrm{AD}$ controls, although the longest living had a virtually complete absence of both plaques and CAA. ${ }^{110} \mathrm{~A}$ CAA-related macrohemorrhage was reported in an $\mathrm{AD}$ patient in phase $2 a$ of $A N 1792 .{ }^{111}$ The findings suggest that $A \beta$ immunization resulted in solubilization of $A \beta 42$ in plaques, which migrates out of the brain parenchyma via perivascular interstitial drainage pathways, causing an increase in CAA and CAA-related hemorrhages. ${ }^{110}$ Menigoencephalitis occurred in $6 \%$ of patients treated in the AN1792 trial, ${ }^{111}$ and perivascular infiltration of lymphocytes was observed around vessels with CAA. ${ }^{112}$ Furthermore, in a phase 2 trial of bapineuzumab, a humanized monoclonal anti-A $\beta$ antibody, amyloid-related imaging abnormalities (ARIA) were reported: vasogenic edema and sulcal effusions (ARIA-E) in 17\%, and microhemorrhages and hemosiderin deposits (ARIA-H) in $47 \%$ of the patients with ARIA$E,{ }^{113}$ suggesting that $A \beta$ immunotherapy resulted in changes in permeability and disruption of CAA-affected vessels. Vasogenic edema was noted in 2 of 2,762 patients with $\mathrm{AD}$ at the baseline of the clinical trial; findings were compatible with CAA-related inflammation. ${ }^{114}$ As discussed above, CAA-related inflammation is associated with the presence of anti-A $\beta$ autoantibodies in $\mathrm{CSF}^{64,65}$ Further studies are required to elucidate the link between $A \beta$ immunotherapy-induced ARIA and CAA-related inflammation.

\section{Future perspectives of prediction, prevention, and therapies for CAA and CAA-related disorders}

Biomarker findings and risk factors for CAA and CAA-related disorders are summarized in Table 3. A number of studies indicate that the presence of one or more biomarkers plus one 
Table 3. Biomarkers and risk factors for cerebral amyloid angiopathy (CAA) and CAA-related disorders

Biomarkers
Biomarkers suggestive of CAA:
Amyloid imaging with greater occipital uptake
A decrease in cerebrospinal fluid (CSF) Aß40 levels
Biomarkers suggestive of CAA-related disorders:
Symptomatic lobar intracerebral hemorrhages on CT/MRI
Microhemorrhages in lobar cortical-subcortical regions on MRI ${ }^{*}$
Cortical superficial siderosis (focal convexity subarachnoid hemorrhages) on MRI*
Cortical microinfarcts on MR ${ }^{\dagger}$
Posterior distribution of white matter hyperintensities on MRI
Severe enlargement of perivascular spaces in the centrum semiovale on MRI
Subacute leukoencephalopathy compatible with CAA-related inflammation/
angiitis on MRI
Presence of anti-Aß antibodies in the CSF for CAA-related inflammation/angiitis
Risk factors
General factors:
Old age
Alzheimer's disease
Genetic factors:
CAA-related gene mutations in familial cases ${ }^{\ddagger}$
Apolipoprotein E gene in sporadic cases: $\varepsilon 4$ for CAA and $\varepsilon 2$ for hemorrhage.
Non-genetic factors for CAA-related hemorrhages:
Thrombolytic, anti-coagulation, and anti-platelet therapies
Hypertension
Minor head trauma
Anti-amyloid therapies

${ }^{*}$ Gradient echo T2* or susceptibility-weighted images are recommended to detect microhemorrhages or focal superficial siderosis.

tFuture development of MRI scanners with a higher spatial resolution is necessary to detect cortical microinfarcts.

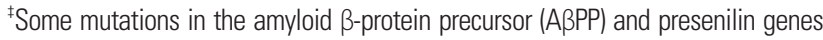
are associated with severe CAA [see review ${ }^{5}$ ].

or more risk factors suggest the future development of CAA-related disorders. Further prospective studies will establish methods for prediction of CAA-related disorders. To develop preventive and therapeutic methods for CAA and CAA-related disorders, their molecular pathogenesis needs to be further elucidated. The molecular pathogenesis of $A \beta$ deposition in cerebral blood vessels is discussed in detail elsewhere [see review ${ }^{5}$.

CAA is not necessarily associated with CAA-related disorders. The pathogenesis of CAA-related disorders consists of two steps: (1) cerebrovascular amyloid deposition and (2) vascular injury including disruption, occlusion, and permeability changes. The cerebrovascular amyloid deposition (Step 1) is the primary target of prevention and therapy. Anti-amyloid therapies for CAA are under development including ponezumab, a humanized monoclonal antibody that binds specifically to the carboxyl terminus of $\mathrm{A} \beta 40 .{ }^{115}$ Ponezumab was originally developed for $\mathrm{AD}$ immunotherapy, and an acceptable safety profile has been suggested for ponezumab in clinical trials for $\mathrm{AD} .{ }^{116-118} \mathrm{Cur}$ rently, ponezumab has been applied to CAA. A phase 2, randomized, double-blind, placebo-controlled trial is ongoing to evaluate the safety, tolerability, pharmacokinetics, and efficacy of ponezumab (PF-04360365) in adult patients with probable CAA-related hemorrhages (NCT01821118). ${ }^{119}$

Vascular injury secondary to cerebrovascular amyloid deposition (Step 2) is an important target for prevention of CAA-related disorders. Risk factors and pathogenic mechanisms underlying vascular injury leading to CAA-related hemorrhages are discussed below. For CAA-related hemorrhages, several nongenetic risk factors have been reported and it is recommended to avoid them. These include thrombolytic, anticoagulation, and anti-platelet therapies, hypertension, and minor head trauma in patients with positive biomarkers of CAA and CAA-related disorders (Table 3). Pathogenic mechanisms underlying the damage and rupture of CAA-affected vessels remain to be determined. Pathologically, severe CAA is associated with vasculopathies including loss of smooth muscle cells, duplication ("double-barrel" lumen), obliterative intimal changes, hyaline degeneration, microaneurysmal dilatation, and fibrinoid necrosis of the vessel walls (Figure 1). ${ }^{12-14}$ Of these, fibrinoid necrosis, in particular, is closely linked to CAA-related hemorrhage. ${ }^{12-14}$ In addition, even in cases without obvious inflammation or angiitis, CAA-affected vessels are associated with an increase in and activation of monocyte/macrophage lineage cells representing immune reactions against vascular amyloid deposition, ${ }^{59}$ which would damage the vessel walls. $A \beta$ deposits in blood vessel walls may trigger release of inflammatory components, activation of the complement system, oxidative stress, alterations in blood brain barrier permeability, formation of ion-like channels, and cell toxicity. ${ }^{120}$ The involvement of matrix metalloproteinases in the degradation of extracellular matrix proteins was suggested in an experimental model and in human brains exhibiting CAA-related ICH. ${ }^{121,122}$ Soluble $A \beta$ oligomers, which are more neurotoxic than insoluble $A \beta$ fibrils, may damage vessel walls affected with CAA. There is increased evidence that $A p o E \varepsilon 2$ is associated with CAA-related ICH and vessel fragility; $;^{87,88,123,124}$ however, ApoE-related pathogenic mechanisms remain to be elucidated. Future preventive/therapeutic strategies for CAA-related hemorrhages should include protection of vessel walls against these factors, as well as the development of anti-amyloid therapies for CAA.

\section{Acknowledgments}

The study was supported in part by a grant from the Amyloidosis Research Committee from the Ministry of Health, Labor and Welfare, Japan, and by the SENSHIN Medical Research Foundation, Japan. The author is grateful to Ms. Etsuko Tsujiguchi for her excellent secretarial work. 


\section{Conflict of interest}

The author declares that the research was conducted in the absence of any commercial or financial relationships that could be construed as a potential conflict of interest.

\section{References}

1. Scholz W. Studien zur Pathologie der Hirngefäße II. Die drusige Entartung der Hirnarterien und Kapillaren. Z ges Neurol Psychiat 1938; 162:694-715.

2. Surbek B. L'angiopathie dyshorique (Morel) de l'écorce cérébrale. Acta Neuropathol 1961;1:168-197.

3. Pantelakis S. Un type particulier d'angiopathie sénile du système nerveux central: l'angiopathice congophile. Topographie et fréquence. Mschr Psychiatr Neurol 1954;128:219-256.

4. Vinters HV. Cerebral amyloid angiopathy. A critical review. Stroke 1987;18:311-324.

5. Yamada M, Naiki H. Cerebral amyloid angiopathy. Prog Mol Biol Transl Sci 2012;51:41-78.

6. Yamada M, Tsukagoshi H, Otomo E, Hayakawa M. Cerebral amyloid angiopathy in the aged. J Neurol 1987;234:371-376.

7. Masuda J, Tanaka K, Ueda K, Omae T. Autopsy study of incidence and distribution of cerebral amyloid angiopathy in $\mathrm{Hi}$ sayama, Japan. Stroke 1988;19:205-210.

8. Yamada M. Risk factors for cerebral amyloid angiopathy in the elderly. Ann N Y Acad Sci 2002;977:37-44.

9. Hirohata M, Yoshita M, Ishida C, Ikeda SI, Tamaoka A, Kuzuhara $\mathrm{S}$, et al. Clinical features of non-hypertensive lobar intracerebral hemorrhage related to cerebral amyloid angiopathy. Eur J Neurol 2010;17:823-829.

10. Yamaguchi H, Yamazaki T, Lemere CA, Frosch MP, Selkoe DJ. Beta amyloid is focally deposited within the outer basement membrane in the amyloid angiopathy of Alzheimer's disease. An immunoelectron microscopic study. Am J Pathol 1992;141: 249-259.

11. Thal DR, Ghebremedhin E, Rub U, Yamaguchi H, Del Tredici $\mathrm{K}, \mathrm{Braak} \mathrm{H}$. Two types of sporadic cerebral amyloid angiopathy. J Neuropathol Exp Neurol 2002;61:282-293.

12. Mandybur TI. Cerebral amyloid angiopathy: the vascular pathology and complications. J Neuropathol Exp Neurol 1986; 45:79-90.

13. Vonsattel JP, Myers RH, Hedley-Whyte ET, Ropper AH, Bird ED, Richardson EP Jr. Cerebral amyloid angiopathy without and with cerebral hemorrhages: a comparative histological study. Ann Neurol 1991;30:637-649.

14. Maeda A, Yamada M, Itoh Y, Otomo E, Hayakawa M, Miyatake T. Computer-assisted three-dimensional image analysis of cerebral amyloid angiopathy. Stroke 1993;24:1857-1864.

15. Prelli F, Castano E, Glenner GG, Frangione B. Differences between vascular and plaque core amyloid in Alzheimer's disease. J Neurochem 1988;51:648-651.

16. Suzuki N, Iwatsubo T, Odaka A, Ishibashi Y, Kitada C, Ihara Y. High tissue content of soluble $\beta 1-40$ is linked to cerebral amyloid angiopathy. Am J Pathol 1994;145:452-460.

17. Weller RO, Massey A, Newman TA, Hutchings M, Kuo YM, Roher AE. Cerebral amyloid angiopathy: amyloid beta accumulates in putative interstitial fluid drainage pathways in Alzheimer's disease. Am J Pathol 1998;153:725-733.

18. Yamada M. Predicting cerebral amyloid angiopathy-related intracerebral hemorrhages and other cerebrovascular disorders in Alzheimer's disease. Front Neurol 2012;3:64.

19. Samarasekera N, Smith C, Al-Shahi Salman R. The association between cerebral amyloid angiopathy and intracerebral haemorrhage: systematic review and meta-analysis. J Neurol Neurosurg Psychiatry 2012;83:275-281.

20. Meretoja A, Strbian D, Putaala J, Curtze S, Haapaniemi E, Mustanoja S, et al. SMASH-U: a proposal for etiologic classification of intracerebral hemorrhage. Stroke 2012;43:25922597.

21. Yeh SJ, Tang SC, Tsai LK, Jeng JS. Pathogenetical subtypes of recurrent intracerebral hemorrhage: designations by SMASHU classification system. Stroke 2014;45:2636-2642.

22. Béjot Y, Cordonnier C, Durier J, Aboa-Eboulé C, Rouaud O, Giroud M. Intracerebral haemorrhage profiles are changing: results from the Dijon population-based study. Brain 2013;136: 658-664.

23. Itoh Y, Yamada M, Hayakawa M, Otomo E, Miyatake T. Cerebral amyloid angiopathy: a significant cause of cerebellar as well as lobar cerebral hemorrhage in the elderly. J Neurol Sci 1993;116:135-141.

24. Yamada M, Itoh Y, Otomo E, Hayakawa M, Miyatake T. Subarachnoid haemorrhage in the elderly: a necropsy study of the association with cerebral amyloid angiopathy. J Neurol Neurosurg Psychiatry 1993;56:543-547.

25. Ohshima T, Endo T, Nukui H, Ikeda S, Allsop D, Onaya T. Cerebral amyloid angiopathy as a cause of subarachnoid hemorrhage. Stroke 1990;21:480-483.

26. Hanyu H, Tanaka Y, Shimizu S, Takasaki M, Abe K. Cerebral microbleeds in Alzheimer's disease. J Neurol 2003;250:14961497.

27. Nakata-Kudo Y, Mizuno T, Yamada K, Shiga K, Yoshikawa K, Mori S, et al. Microbleeds in Alzheimer disease are more related to cerebral amyloid angiopathy than cerebrovascular disease. Dement Geriatr Cogn Disord 2006;22:8-14.

28. Cordonnier C, van der Flier WM, Sluimer JD, Leys D, Bark- 
hof F, Scheltens P. Prevalence and severity of microbleeds in a memory clinic setting. Neurology 2006;66:1356-1360.

29. Cordonnier C, Al-Shahi Salman R, Wardlaw J. Spontaneous brain microbleeds: systematic review, subgroup analyses and standards for study design and reporting. Brain 2007;130: 1988-2003.

30. Pettersen JA, Sathiyamoorthy G, Gao FQ, Szilagyi G, Nadkarni NK, St George-Hyslop P, et al. Microbleed topography, leukoaraiosis, and cognition in probable Alzheimer disease from the Sunnybrook dementia study. Arch Neurol 2008;65:790795.

31. Brundel M, Heringa SM, de Bresser J, Koek HL, Zwanenburg JJ, Jaap Kappelle L, et al. High prevalence of cerebral microbleeds at 7Tesla MRI in patients with early Alzheimer's disease. J Alzheimers Dis 2012;31:259-263.

32. Linn J, Halpin A, Demaerel P, Ruhland J, Giese AD, Dichgans $\mathrm{M}$, et al. Prevalence of superficial siderosis in patients with cerebral amyloid angiopathy. Neurology 2010;74:1346-1350.

33. Yates PA, Sirisriro R, Villemagne VL, Farquharson S, Masters $\mathrm{CL}$, Rowe CC, et al. Cerebral microhemorrhage and brain $\beta$-amyloid in aging and Alzheimer disease. Neurology 2011; 77:48-54.

34. Dierksen GA, Skehan ME, Khan MA, Jeng J, Nandigam RN, Becker JA, et al. Spatial relation between microbleeds and amyloid deposits in amyloid angiopathy. Ann Neurol 2010;68: 545-548.

35. Gurol ME, Dierksen G, Betensky R, Gidicsin C, Halpin A, Becker A, et al. Predicting sites of new hemorrhage with amyloid imaging in cerebral amyloid angiopathy. Neurology 2012; 79:320-326.

36. van Etten ES, Auriel E, Haley KE, Ayres AM, Vashkevich A, Schwab KM, et al. Incidence of symptomatic hemorrhage in patients with lobar microbleeds. Stroke 2014;45:2280-2285.

37. Feldman HH, Maia LF, Mackenzie IR, Forster BB, Martzke J, Woolfenden A. Superficial siderosis: a potential diagnostic marker of cerebral amyloid angiopathy in Alzheimer disease. Stroke 2008;39:2894-2897.

38. Kumar S, Goddeau RP Jr, Selim MH, Thomas A, Schlaug G, Alhazzani A, et al. Atraumatic convexal subarachnoid hemorrhage: clinical presentation, imaging patterns, and etiologies. Neurology 2010;74:893-899.

39. Vernooij MW, Ikram MA, Hofman A, Krestin GP, Breteler $\mathrm{MM}$, van der Lugt A. Superficial siderosis in the general population. Neurology 2009; 73:202-205.

40. Charidimou A, Peeters AP, Jäger R, Fox Z, Vandermeeren Y, Laloux $\mathrm{P}$, et al. Cortical superficial siderosis and intracerebral hemorrhage risk in cerebral amyloid angiopathy. Neurology 2013;81:1666-1673.
41. Shoamanesh A, Martinez-Ramirez S, Oliveira-Filho J, Reijmer Y, Falcone GJ, Ayres A, et al. Interrelationship of superficial siderosis and microbleeds in cerebral amyloid angiopathy. Neurology 2014;83:1838-1843.

42. Linn J, Wollenweber FA, Lummel N, Bochmann K, Pfefferkorn T, Gschwendtner A, et al. Superficial siderosis is a warning sign for future intracranial hemorrhage. J Neurol 2013; 260:176-181.

43. Wollenweber FA, Buerger K, Mueller C, Ertl-Wagner B, Malik $\mathrm{R}$, Dichgans $\mathrm{M}$, et al. Prevalence of cortical superficial siderosis in patients with cognitive impairment. J Neurol 2014;261: 277-282.

44. Zonneveld HI, Goos JD, Wattjes MP, Prins ND, Scheltens P, van der Flier WM, et al. Prevalence of cortical superficial siderosis in a memory clinic population. Neurology 2014;82:698704.

45. Izenberg A, Aviv RI, Demaerschalk BM, Dodick DW, Hopyan J, Black SE, et al. Crescendo transient aura attacks: a transient ischemic attack mimic caused by focal subarachnoid hemorrhage. Stroke 2009;40:3725-3729.

46. Beitzke M, Gattringer T, Enzinger C, Wagner G, Niederkorn K, Fazekas F. Clinical presentation, etiology, and long-term prognosis in patients with nontraumatic convexal subarachnoid hemorrhage. Stroke 2011;42:3055-3060.

47. Charidimou A, Peeters A, Fox Z, Gregoire SM, Vandermeeren Y, Laloux P, et al. Spectrum of transient focal neurological episodes in cerebral amyloid angiopathy: multicentre magnetic resonance imaging cohort study and meta-analysis. Stroke 2012; 43:2324-2330.

48. Apoil M, Cogez J, Dubuc L, Bataille M, de la Sayette V, Touzé $\mathrm{E}$, et al. Focal cortical subarachnoid hemorrhage revealed by recurrent paresthesias: a clinico-radiological syndrome strongly associated with cerebral amyloid angiopathy. Cerebrovasc Dis 2013;36:139-144.

49. Charidimou A, Baron JC, Werring DJ. Transient focal neurological episodes, cerebral amyloid angiopathy, and intracerebral hemorrhage risk: looking beyond TIAs. Int J Stroke 2013; 8:105-108.

50. Zhu YC, Chabriat H, Godin O, Dufouil C, Rosand J, Greenberg SM, et al. Distribution of white matter hyperintensity in cerebral hemorrhage and healthy aging. J Neurol 2012;259: 530-536.

51. Thanprasertsuk S, Martinez-Ramirez S, Pontes-Neto OM, Ni J, Ayres A, Reed A, et al. Posterior white matter disease distribution as a predictor of amyloid angiopathy. Neurology 2014; 83:794-800.

52. Gurol ME, Viswanathan A, Gidicsin C, Hedden T, MartinezRamirez S, Dumas A, et al. Cerebral amyloid angiopathy bur- 
den associated with leukoaraiosis: a positron emission tomography/magnetic resonance imaging study. Ann Neurol 2013; 73:529-536.

53. Kimberly WT, Gilson A, Rost NS, Rosand J, Viswanathan A, Smith EE, et al. Silent ischemic infarcts are associated with hemorrhage burden in cerebral amyloid angiopathy. Neurology 2009;72:1230-1235.

54. Gregoire SM, Charidimou A, Gadapa N, Dolan E, Antoun N, Peeters A, et al. Acute ischaemic brain lesions in intracerebral haemorrhage: multicentre cross-sectional magnetic resonance imaging study. Brain 2011;134:2376-2386.

55. Vallat W, Maundrell A, Leyden J, Kleinig TJ. Cerebral amyloid angiopathy causing cortical microinfarction. J Clin Neurosci 2013;20:1802-1804.

56. Yamada M, Itoh Y, Suematsu N, Otomo E, Matsushita M. Vascular variant of Alzheimer's disease characterized by severe plaque-like beta protein angiopathy. Dement Geriatr Cogn Disord 1997;8:163-168.

57. Cordonnier C, Leys D, Dumont F, Deramecourt V, Bordet R, Pasquier F, et al. What are the causes of pre-existing dementia in patients with intracerebral haemorrhages? Brain 2010;133: 3281-3289.

58. Arvanitakis Z, Leurgans SE, Wang Z, Wilson RS, Bennett DA, Schneider JA. Cerebral amyloid angiopathy pathology and cognitive domains in older persons. Ann Neurol 2011;69:320327.

59. Yamada M, Itoh Y, Shintaku M, Kawamura J, Jensson O, Thorsteinsson L, et al. Immune reactions associated with cerebral amyloid angiopathy. Stroke 1996;27:1155-1162.

60. Oh U, Gupta R, Krakauer JW, Khandji AG, Chin SS, Elkind MS. Reversible leukoencephalopathy associated with cerebral amyloid angiopathy. Neurology 2004;62:494-497.

61. Eng JA, Frosch MP, Choi K, Rebeck GW, Greenberg SM. Clinical manifestations of cerebral amyloid angiopathy-related inflammation. Ann Neurol 2004;55:250-256.

62. Scolding NJ, Joseph F, Kirby PA, Mazanti I, Gray F, Mikol J, et al. A $\beta$-related angiitis: primary angiitis of the central nervous system associated with cerebral amyloid angiopathy. Brain 2005; 128:500-515.

63. Kinnecom C, Lev MH, Wendell L, Smith EE, Rosand J, Frosch $\mathrm{MP}$, et al. Course of cerebral amyloid angiopathy-related inflammation. Neurology 2007;68:1411-1416.

64. DiFrancesco JC, Brioschi M, Brighina L, Ruffmann C, Saracchi E, Costantino G, et al. Anti-A $\beta$ autoantibodies in the CSF of a patient with CAA-related inflammation: a case report. Neurology 2011;76:842-844.

65. Piazza F, Greenberg SM, Savoiardo M, Gardinetti M, Chiapparini L, Raicher I, et al. Anti-amyloid $\beta$ autoantibodies in ce- rebral amyloid angiopathy-related inflammation: implications for amyloid-modifying therapies. Ann Neurol 2013;73:449458.

66. Nandigam RN, Viswanathan A, Delgado P, Skehan ME, Smith EE, Rosand J, et al. MR imaging detection of cerebral microbleeds: effect of susceptibility-weighted imaging, section thickness, and field strength. AJNR Am J Neuroradiol 2009; 30:338-343.

67. Ii Y, Maeda M, Kida H, Matsuo K, Shindo A, Taniguchi A, et al. In vivo detection of cortical microinfarcts on ultrahigh-field MRI. J Neuroimaging 2013;23:28-32.

68. Radmanesh F, Falcone GJ, Anderson CD, Battey TW, Ayres AM, Vashkevich A, et al. Risk factors for computed tomography angiography spot sign in deep and lobar intracerebral hemorrhage are shared. Stroke 2014;45:1833-1835.

69. Charidimou A, Meegahage R, Fox Z, Peeters A, Vandermeeren Y, Laloux P, et al. Enlarged perivascular spaces as a marker of underlying arteriopathy in intracerebral haemorrhage: a multicentre MRI cohort study. J Neurol Neurosurg Psychiatry 2013; 84:624-629.

70. Charidimou A, Jaunmuktane Z, Baron JC, Burnell M, Varlet P, Peeters A, et al. White matter perivascular spaces: an MRI marker in pathology-proven cerebral amyloid angiopathy? Neurology 2014;82:57-62.

71. Charidimou A, Jäger RH, Peeters A, Vandermeeren Y, Laloux $\mathrm{P}$, Baron JC, et al. White matter perivascular spaces are related to cortical superficial siderosis in cerebral amyloid angiopathy. Stroke 2014;45:2930-2935.

72. Smith EE, Vijayappa M, Lima F, Delgado P, Wendell L, Rosand $\mathrm{J}$, et al. Impaired visual evoked flow velocity response in cerebral amyloid angiopathy. Neurology 2008;71:1424-1430.

73. Dumas A, Dierksen GA, Gurol ME, Halpin A, MartinezRamirez S, Schwab K, et al. Functional magnetic resonance imaging detection of vascular reactivity in cerebral amyloid angiopathy. Ann Neurol 2012;72:76-81.

74. Peca S, McCreary CR, Donaldson E, Kumarpillai G, Shobha $\mathrm{N}$, Sanchez K, et al. Neurovascular decoupling is associated with severity of cerebral amyloid angiopathy. Neurology 2013; 81:1659-1665.

75. Johnson KA, Gregas M, Becker JA, Kinnecom C, Salat DH, Moran EK, et al. Imaging of amyloid burden and distribution in cerebral amyloid angiopathy. Ann Neurol 2007;62:229-234.

76. Bacskai BJ, Frosch MP, Freeman SH, Raymond SB, Augustinack JC, Johnson KA, et al. Molecular imaging with Pittsburgh Compound B confirmed at autopsy: a case report. Arch Neurol 2007;64:431-434.

77. Ly JV, Donnan GA, Villemagne VL, Zavala JA, Ma H, O’Keefe $\mathrm{G}$, et al. 11C-PIB binding is increased in patients with cerebral 
amyloid angiopathy-related hemorrhage. Neurology 2010;74: 487-493.

78. Baron JC, Farid K, Dolan E, Turc G, Marrapu ST, O’Brien E, et al. Diagnostic utility of amyloid PET in cerebral amyloid angiopathy-related symptomatic intracerebral hemorrhage. J Cereb Blood Flow Metab 2014;34:753-758.

79. Rutgers KS, van Remoortere A, van Buchem MA, Verrips CT, Greenberg SM, Bacskai BJ, et al. Differential recognition of vascular and parenchymal beta amyloid deposition. Neurobiol Aging 2011;32:1774-1783.

80. Verbeek MM, Kremer BP, Rikkert MO, Van Domburg PH, Skehan ME, Greenberg SM. Cerebrospinal fluid amyloid $\beta 40$ is decreased in cerebral amyloid angiopathy. Ann Neurol 2009; 66:245-249.

81. Renard D, Castelnovo G, Wacongne A, Le Floch A, Thouvenot $\mathrm{E}$, Mas J, et al. Interest of CSF biomarker analysis in possible cerebral amyloid angiopathy cases defined by the modified Boston criteria. J Neurol 2012;259:2429-2433.

82. Hernandez-Guillamon M, Delgado P, Penalba A, RodriguezLuna D, Molina CA, Rovira A, et al. Plasma $\beta$-amyloid levels in cerebral amyloid angiopathy-associated hemorrhagic stroke. Neurodegener Dis 2012;10:320-323.

83. Knudsen KA, Rosand J, Karluk D, Greenberg SM. Clinical diagnosis of cerebral amyloid angiopathy: validation of the Boston criteria. Neurology 2001;56:537-539.

84. Greene GM, Godersky JC, Biller J, Hart MN, Adams HP Jr. Surgical experience with cerebral amyloid angiopathy. Stroke 1990;21:1545-1549.

85. Greenberg SM, Rebeck GW, Vonsattel JP, Gomez-Isla T, Hyman BT. Apolipoprotein E $\varepsilon 4$ and cerebral hemorrhage associated with amyloid angiopathy. Ann Neurol 1995;38:254259.

86. Premkumar DR, Cohen DL, Hedera P, Friedland RP, Kalaria

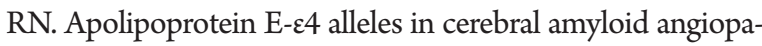
thy and cerebrovascular pathology associated with Alzheimer's disease. Am J Pathol 1996;148:2083-2095.

87. Nicoll JA, Burnett C, Love S, Graham DI, Dewar D, Ironside $\mathrm{JW}$, et al. High frequency of apolipoprotein E $\varepsilon 2$ allele in hemorrhage due to cerebral amyloid angiopathy. Ann Neurol 1997; 41:716-721.

88. Brouwers HB, Biffi A, McNamara KA, Ayres AM, Valant V, Schwab K, et al. Apolipoprotein E genotype is associated with $\mathrm{CT}$ angiography spot sign in lobar intracerebral hemorrhage. Stroke 2012;43:2120-2125.

89. O’Donnell HC, Rosand J, Knudsen KA, Furie KL, Segal AZ, Chiu RI, et al. Apolipoprotein E genotype and the risk of recurrent lobar intracerebral hemorrhage. N Engl J Med 2000; 342:240-245.
90. Maxwell SS, Jackson CA, Paternoster L, Cordonnier C, Thijs V, Al-Shahi Salman R, et al. Genetic associations with brain microbleeds: systematic review and meta-analyses. Neurology 2011;77:158-167.

91. Leclercq PD, Murray LS, Smith C, Graham DI, Nicoll JA, Gentleman SM. Cerebral amyloid angiopathy in traumatic brain injury: association with apolipoprotein E genotype. J Neurol Neurosurg Psychiatry 2005;76:229-233.

92. Hamaguchi T, Okino S, Sodeyama N, Itoh Y, Takahashi A, Otomo E, et al. Association of a polymorphism of the transforming growth factor- $\beta 1$ gene with cerebral amyloid angiopathy. J Neurol Neurosurg Psychiatry 2005;76:696-699.

93. Peila R, Yucesoy B, White LR, Johnson V, Kashon ML, Wu K, et al. A TGF- $\beta 1$ polymorphism association with dementia and neuropathologies: the HAAS. Neurobiol Aging 2007;28: 1367-1373.

94. Yamada M. Cerebral amyloid angiopathy and gene polymorphisms. J Neurol Sci 2004;226:41-44.

95. Yamada M, Sodeyama N, Itoh Y, Suematsu N, Otomo E, Matsushita M, et al. Association of presenilin-1 polymorphism with cerebral amyloid angiopathy in the elderly. Stroke 1997; 28:2219-2221.

96. Yamada M, Sodeyama N, Itoh Y, Suematsu N, Otomo E, Matsushita $\mathrm{M}$, et al. Association of al-antichymotrypsin polymorphism with cerebral amyloid angiopathy. Ann Neurol 1998; 44:129-131.

97. Yamada M, Sodeyama N, Itoh Y, Takahashi A, Otomo E, Matsushita $\mathrm{M}$, et al. Association of neprilysin polymorphism with cerebral amyloid angiopathy. J Neurol Neurosurg Psychiatry 2003;74:749-751.

98. Christoforidis M, Schober R, Krohn K. Genetic-morphologic association study: association between the low density lipoprotein-receptor related protein (LRP) and cerebral amyloid angiopathy. Neuropathol Appl Neurobiol 2005;31:11-19.

99. Domingues-Montanari S, Hernandez-Guillamon M, Fernandez-Cadenas I, Mendioroz M, Boada M, Munuera J, et al. ACE variants and risk of intracerebral hemorrhage recurrence in amyloid angiopathy. Neurobiol Aging 2011;32:551.

100. Thal DR, Papassotiropoulos A, Saido TC, Griffin WS, Mrak $\mathrm{RE}, \mathrm{Kolsch} \mathrm{H}$, et al. Capillary cerebral amyloid angiopathy identifies a distinct APOE $\varepsilon 4$-associated subtype of sporadic Alzheimer's disease. Acta Neuropathol 2010;120:169-183.

101. Biffi A, Shulman JM, Jagiella JM, Cortellini L, Ayres AM, Schwab K, et al. Genetic variation at CR1 increases risk of cerebral amyloid angiopathy. Neurology 2012;78:334-341.

102. Arima H, Tzourio C, Anderson C, Woodward M, Bousser MG, MacMahon S, et al. Effects of perindopril-based lowering of blood pressure on intracerebral hemorrhage related to 
amyloid angiopathy: the PROGRESS trial. Stroke 2010;41: 394-396.

103. Rosand J, Hylek EM, O’Donnell HC, Greenberg SM. Warfarin-associated hemorrhage and cerebral amyloid angiopathy: a genetic and pathologic study. Neurology 2000;55:947-951.

104. McCarron MO, Nicoll JA. Cerebral amyloid angiopathy and thrombolysis-related intracerebral haemorrhage. Lancet Neurol 2004;3:484-492

105. Charidimou A, Kakar P, Fox Z, Werring DJ. Cerebral microbleeds and the risk of intracerebral haemorrhage after thrombolysis for acute ischaemic stroke: systematic review and meta-analysis. J Neurol Neurosurg Psychiatry 2013;84:277-280.

106. Charidimou A, Shakeshaft C, Werring DJ. Cerebral microbleeds on magnetic resonance imaging and anticoagulant-associated intracerebral hemorrhage risk. Front Neurol 2012;3: 133.

107. Falcone GJ, Radmanesh F, Brouwers HB, Battey TW, Devan WJ, Valant V, et al. APOE $\varepsilon$ variants increase risk of warfarinrelated intracerebral hemorrhage. Neurology 2014;83:11391146.

108. Vernooij MW, Haag MD, van der Lugt A, Hofman A, Krestin GP, Stricker BH, et al. Use of antithrombotic drugs and the presence of cerebral microbleeds: the Rotterdam Scan Study. Arch Neurol 2009;66:714-720.

109. Thoonsen H, Richard E, Bentham P, Gray R, van Geloven N, De Haan RJ, et al. Aspirin in Alzheimer's disease: increased risk of intracerebral hemorrhage: cause for concern? Stroke 2010;41:2690-2692.

110. Boche D, Zotova E, Weller RO, Love S, Neal JW, Pickering $\mathrm{RM}$, et al. Consequence of $\mathrm{A} \beta$ immunization on the vasculature of human Alzheimer's disease brain. Brain 2008;131:32993310.

111. Orgogozo JM, Gilman S, Dartigues JF, Laurent B, Puel M, Kirby LC, et al. Subacute meningoencephalitis in a subset of patients with $\mathrm{AD}$ after $\mathrm{A} \beta 42$ immunization. Neurology 2003; 61:46-54.

112. Nicoll JA, Wilkinson D, Holmes C, Steart P, Markham H, Weller RO. Neuropathology of human Alzheimer disease after immunization with amyloid- $\beta$ peptide: a case report. Nat Med 2003;9:448-452.

113. Sperling R, Salloway S, Brooks DJ, Tampieri D, Barakos J, Fox $\mathrm{NC}$, et al. Amyloid-related imaging abnormalities in patients with Alzheimer's disease treated with bapineuzumab: a retrospective analysis. Lancet Neurol 2012;11:241-249.

114. Carlson C, Estergard W, Oh J, Suhy J, Jack CR, Siemers E, et al. Prevalence of asymptomatic vasogenic edema in pretreat- ment Alzheimer's disease study cohorts from phase 3 trials of semagacestat and solanezumab. Alzheimers Dement 2011;7: 396-401.

115. La Porte SL, Bollini SS, Lanz TA, Abdiche YN, Rusnak AS, Ho $\mathrm{WH}$, et al. Structural basis of C-terminal $\beta$-amyloid peptide binding by the antibody ponezumab for the treatment of Alzheimer's disease. J Mol Biol 2012;421:525-536.

116. Miyoshi I, Fujimoto Y, Yamada M, Abe S, Zhao Q, Cronenberger C, et al. Safety and pharmacokinetics of PF-04360365 following a single-dose intravenous infusion in Japanese subjects with mild-to-moderate Alzheimer's disease: a multicenter, randomized, double-blind, placebo-controlled, doseescalation study. Int J Clin Pharmacol Ther 2013;51:911-923.

117. Burstein AH, Zhao Q Ross J, Styren S, Landen JW, Ma WW, et al. Safety and pharmacology of ponezumab (PF-04360365) after a single 10-minute intravenous infusion in subjects with mild to moderate Alzheimer disease. Clin Neuropharmacol 2013;36:8-13.

118. Landen JW, Zhao Q, Cohen S, Borrie M, Woodward M, Billing $\mathrm{CB}$, et al. Safety and pharmacology of a single intravenous dose of ponezumab in subjects with mild-to-moderate Alzheimer disease: a phase I, randomized, placebo-controlled, double-blind, dose-escalation study. Clin Neuropharmacol 2013;36:14-23.

119. ClinicalTrials.gov. https://clinicaltrials.gov. Accessed on November 7, 2014.

120. Revesz T, Holton JL, Lashley T, Plant G, Frangione B, Rostagno $\mathrm{A}$, et al. Genetics and molecular pathogenesis of sporadic and hereditary cerebral amyloid angiopathies. Acta Neuropathol 2009; 118:115-130.

121. Hernandez-Guillamon M, Martinez-Saez E, Delgado P, Domingues-Montanari S, Boada C, Penalba A, et al. MMP-2/ MMP-9 plasma level and brain expression in cerebral amyloid angiopathy-associated hemorrhagic stroke. Brain Pathol 2012; 22:133-141.

122. Lee JM, Yin K, Hsin I, Chen S, Fryer JD, Holtzman DM, et al. Matrix metalloproteinase-9 in cerebral-amyloid-angiopathyrelated hemorrhage. J Neurol Sci 2005;229-230:249-254.

123. McCarron MO, Nicoll JA, Stewart J, Ironside JW, Mann DM, Love $S$, et al. The apolipoprotein $\mathrm{E} \varepsilon 2$ allele and the pathological features in cerebral amyloid angiopathy-related hemorrhage. J Neuropathol Exp Neurol 1999;58:711-718.

124. Biffi A, Anderson CD, Jagiella JM, Schmidt H, Kissela B, Hansen BM, et al. APOE genotype and extent of bleeding and outcome in lobar intracerebral haemorrhage: a genetic association study. Lancet Neurol 2011;10:702-709. 